\title{
INDUCTION OF ENHANCED METHANE OXIDATION IN COMPOST: TEMPERATURE AND MOISTURE RESPONSE
}

\author{
Suman Mor ${ }^{\mathrm{a}, \mathrm{b}^{*}}$, Alex De Visscher ${ }^{\mathrm{b}, \mathrm{d}}$, Khaiwal Ravindra ${ }^{\mathrm{c}}$, R. P. Dahiya ${ }^{\mathrm{a}}$, A. \\ Chandra $^{a}$ and Oswald Van Cleemput ${ }^{b}$
}

${ }^{\text {a }}$ Centre for Energy Studies, Indian Institute of Technology Delhi, Hauz Khas, New Delhi-110016, India

\footnotetext{
${ }^{\mathrm{b}}$ Department of Applied Analytical and Physical Chemistry, Ghent University, Coupure Links 653, B-9000 Ghent, Belgium
}

${ }^{c}$ Micro and Trace Analysis Centre, Department of Chemistry, University of Antwerp, Universiteitsplein 1, B-2610 Antwerp, Belgium

\footnotetext{
${ }^{\mathrm{d}}$ Present address: Department of Chemical \& Petroleum Engineering, University of Calgary, 2500 University Drive N.W., Calgary, Alberta, T2N 1N4, Canada
}

*Corresponding author: Suman Mor (umanmor@yahoo.com). 


\begin{abstract}
Landfilling is one of the most common ways of municipal solid waste disposal. Degradation of organic waste produces $\mathrm{CH}_{4}$ and other landfill gases that significantly contribute to global warming. However, before entering the atmosphere, part of the produced $\mathrm{CH}_{4}$ can be oxidised while passing through the landfill cover. In the present study the oxidation rate of $\mathrm{CH}_{4}$ was studied with various types of compost as possible landfill cover. The influence of incubation time, moisture content and temperature on the $\mathrm{CH}_{4}$ oxidation capacity of different types of compost was examined. It was observed that the influence of moisture content and temperature on methane oxidation is time-dependent. Maximum oxidation rates were observed at moisture contents ranging from $45 \%$ to $110 \%$ (dry weight basis), while the optimum temperature ranged from 15 to $30^{\circ} \mathrm{C}$.
\end{abstract}

Key words: $\mathrm{CH}_{4}$ oxidation, greenhouse gas, compost, landfill, landfill gas. 


\section{Introduction}

Methane $\left(\mathrm{CH}_{4}\right)$ accounts for approximately $22 \%$ of the enhanced global warming (Lelieveld et al., 1998). Relative to $\mathrm{CO}_{2}$, the global warming potential of $\mathrm{CH}_{4}$ is estimated at 23 using a 100-year time horizon (IPCC, 2001). The atmospheric concentration of $\mathrm{CH}_{4}$ has increased from a concentration of $700 \mathrm{ppb}$ to $1745 \mathrm{ppb}$ between the years 1750 and 1998 (IPCC, 2001).

Landfilling is considered to be an important global source of this greenhouse gas. Emissions of $\mathrm{CH}_{4}$ from waste landfills are ranked third among anthropogenic $\mathrm{CH}_{4}$ sources and range between 19-40 Tg/yr (Doorn and Barlaz, 1995; Bogner and Matthews, 2003). These emissions are mainly caused by inadequate gas collection systems, uncontrolled emissions from old dumps and from unauthorized open dumping. Furthermore, because of the increase in population in developing countries, $\mathrm{CH}_{4}$ emissions are estimated to increase by up to $60 \%$ within the next two decades (Meadows et al., 1997). Landfill gas extraction from smaller and older landfills with low $\mathrm{CH}_{4}$ generation rates is economically not beneficial.

A low-cost approach such as increasing microbial activity to increase $\mathrm{CH}_{4}$ oxidation using a suitable cover layer can help reducing $\mathrm{CH}_{4}$ emissions from landfills. Approximately $60 \%$ of the $\mathrm{CH}_{4}$ produced from anthropogenic and natural sources is oxidised microbially adjacent to the zone of production or in soils functioning as atmospheric sinks (Reeburgh et al., 1993; Bender and Conrad, 1995).

$\mathrm{CH}_{4}$ oxidation in conventional soil covers, typically of older landfills, has been reported to be effective in reducing the amount of $\mathrm{CH}_{4}$ emitted (Bogner et al., 1997; Chanton and Liptay, 2000; Börjesson et al., 2001). The oxidation rate depends on different environmental factors including moisture and temperature (King and Adamsen, 1992; Adamsen and King 1993; Boeckx and Van Cleemput, 1996; Whalen 
and Reeburgh 1996; Visvanathan et al., 1999; De Visscher et al., 2001). The effect of inorganic nitrogen on $\mathrm{CH}_{4}$ oxidation is very complex and can be both stimulatory and inhibitive (Bodelier and Laanbroek, 2004). De Visscher and Van Cleemput (2003) found that the influence of ammonium and chloride on $\mathrm{CH}_{4}$ oxidation by soils is time dependent. Time dependence of the influence of temperature and moisture on $\mathrm{CH}_{4}$ oxidation has never been studied systematically. However, Gebert et al. (2003) and Börjesson et al. (2004) found that methanotrophic enrichments cultured at $10^{\circ} \mathrm{C}$ lead to a shift towards more type I methanotrophs with a lower optimum temperature, indicating that temperature response in media like soil or compost might be timedependent.

$\mathrm{CH}_{4}$ oxidation rates in conventional soils have been studied extensively, but there are fewer studies on environmental factors influencing the rate of $\mathrm{CH}_{4}$ oxidation in compost. Streese and Stegmann (2003) studied compost as biofilter material for microbial $\mathrm{CH}_{4}$ degradation and reported high degradation rates of up to $63 \mathrm{~g} \mathrm{CH}_{4} \mathrm{~m}^{-3}$ $\mathrm{h}^{-1}$. Wilshusen et al. (2004a,b) studied $\mathrm{CH}_{4}$ oxidation and formation of exopolymeric substances in compost for the performance of $\mathrm{CH}_{4}$ biofilters and the effect of oxygen concentration. Humer and Lechner (1999, 2001) studied municipal solid waste compost and sewage sludge compost as cover soil to increase oxidation of $\mathrm{CH}_{4}$ and found that complete $\mathrm{CH}_{4}$ oxidation is possible. Barlaz et al. (2004) reported that compost covers oxidized more $\mathrm{CH}_{4}$ than conventional clay covers in field trials, but warned that compost covers can also produce $\mathrm{CH}_{4}$ if the moisture content is too high.

In the present study experiments were performed at laboratory scale to examine how $\mathrm{CH}_{4}$ oxidation depends on temperature and moisture for different types of compost and to assess the suitability of compost as landfill cover. Particular attention was given to the time dependence of these influences, an aspect that has 
received little or no attention to date. The $\mathrm{CH}_{4}$ oxidation capacity of compost will help to determine its potential usefulness to landfill operators as a tool to curb $\mathrm{CH}_{4}$ emissions in order to meet regulatory requirements.

\section{Materials and Methods}

\subsection{Compost characteristics and analysis}

Table 1 shows the characteristics of the composts used in this study. They were obtained from VLACO, Mechelen, Belgium. Two mixed kitchen and garden waste composts (labelled GFT1 and GFT2) were tested, together with three garden waste composts (labelled G1, G2 and G3). GFT1 was produced by intensive aeration in a compost hall; GFT2 by intensive aeration in a compost tunnel. G1 was produced by intensive aeration for 3 months, whereas G2 and G3 were produced by passive aeration for 6 months. All compost samples were analysed by VLACO. Compost moisture contents were determined gravimetrically, by drying 10-g samples for $48 \mathrm{~h}$ at $105{ }^{\circ} \mathrm{C}$. $\mathrm{pH}$ was measured by shaking $20 \mathrm{ml}$ of compost in $100 \mathrm{ml}$ of water for 24 hours and analysis by $\mathrm{pH}$ meter. Electrical conductivity was determined in similar extracts. Organic matter was determined gravimetrically by heating to $550^{\circ} \mathrm{C}$ for 4 hours. Organic carbon content was assumed to be organic matter content divided by 1.8. Total nitrogen was determined by Kjeldahl destruction followed by steam distillation and capturing the resulting ammonia in boric acid, and back titration of the resulting ammonium borate with $\mathrm{HCl}$. For inorganic $\mathrm{N}$ analysis, 30-g samples were extracted with $60 \mathrm{ml} 2 \mathrm{M} \mathrm{KCl}$ by shaking for $1 \mathrm{~h}$ and then the compost slurry was filtered. The $\mathrm{NH}_{4}{ }^{+}$, nitrate and nitrite contents were analysed by auto analyser (Bran + Luebbe Auto Analyser 3). Additional compost samples were used for kinetic experiments of methane oxidation as described in the next section. 


\subsection{Kinetic experiments}

The batch experiments were carried out at room temperature $\left(22 \pm 1^{\circ} \mathrm{C}\right)$ in glass bottles. All kinetic experiments were performed in duplicate. About $30 \mathrm{~g}$ of the compost samples was transferred into $215-\mathrm{ml}$ bottles that can be closed with a rubber septum. Each test bottle was injected with $10 \mathrm{ml}$ of $100 \% \mathrm{CH}_{4}$, leading to an initial $\mathrm{CH}_{4}$ concentration of about $5 \%$. The bottles were sampled periodically with an interval of 30-60 minutes to determine the $\mathrm{CH}_{4}$ consumption. Typically 5 samples

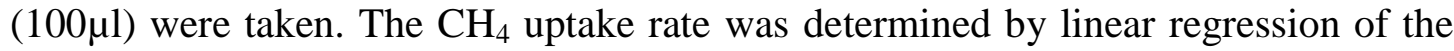
measured $\mathrm{CH}_{4}$ concentration versus time.

To determine the respiration activity of the compost about $30 \mathrm{~g}$ of fresh compost samples not previously exposed to $\mathrm{CH}_{4}$ were transferred into $215-\mathrm{ml}$ bottles, closed with rubber septa and the concentration of $\mathrm{CO}_{2}$ was determined at different times at $22^{\circ} \mathrm{C}$. The $\mathrm{CO}_{2}$ production rate was determined by linear regression of the $\mathrm{CO}_{2}$ concentration versus time.

\subsection{Compost incubations}

\subsubsection{Influence of incubation time}

Incubations were carried out in batch mode because this technique enables accurate moisture control by gravimetry. It has been shown that column experiments can lead to moisture loss, accumulation and redistribution, both in forced-aeration mode (De Visscher and Van Cleemput, 2003) as in passive-aeration (countergradient) mode (Stein and Hettiaratchi, 2001).

The compost taken to measure the effect of incubation time on $\mathrm{CH}_{4}$ oxidation rate was fresh and not previously exposed to $\mathrm{CH}_{4}$. All five compost samples were 
incubated in 215 -ml bottles at $22 \pm 1{ }^{\circ} \mathrm{C}$ to test their potential to oxidise $\mathrm{CH}_{4}$. When $\mathrm{CH}_{4}$ or $\mathrm{O}_{2}$ was depleted the bottles were opened for about 15 minutes for aeration, closed again and $10 \mathrm{ml} \mathrm{CH}$ was added, leading to a headspace mixing ratio of approximately $5 \%$. This procedure was repeated until the end of the incubation.

\subsubsection{Influence of moisture content}

To test the influence of moisture content, fresh samples of the most active composts (G1 and G3) were pre-incubated in jars with $\mathrm{CH}_{4}$ at room temperature of $22 \pm 1^{\circ} \mathrm{C}$ by periodically adding $10 \% \mathrm{CH}_{4}$ after aeration. The incubation time in the jars was two weeks for compost G1 and five weeks for G3. The moisture response of $\mathrm{CH}_{4}$ oxidation was determined by adjusting samples to different moisture contents, transferring them to bottles and measuring the $\mathrm{CH}_{4}$ oxidation rate. The moisture contents tested were $29,45,65,85$ and $110 \%$ for G1 and 34, 52, 72, 92 and $110 \%$ (w/w) for G3. All moisture percentages are expressed on a dry weight basis. Moisture contents were increased by adding demineralised water and decreased by evaporating the water content to the desired level. $30 \mathrm{~g}$ of sample were brought into the bottles and acclimatised overnight with changed moisture content at a temperature of $22 \pm 1^{\circ} \mathrm{C}$.

\subsubsection{Influence of temperature}

To test the influence of temperature, fresh samples of the most active composts (G1 and G3) were pre-incubated in jars with $\mathrm{CH}_{4}$ at a temperature of $22 \pm 1^{\circ} \mathrm{C}$ by periodically adding $10 \% \mathrm{CH}_{4}$ after aeration. The incubation time in the jars was two weeks for compost G1 while for G3 it was five weeks. $30 \mathrm{~g}$ of sample was brought into the bottles and acclimatised overnight at a temperature of $7,15,22,30$ 
and $40^{\circ} \mathrm{C}$. The $\mathrm{CH}_{4}$ oxidation rate was measured by determining the decrease of $\mathrm{CH}_{4}$ versus time after addition of $10 \mathrm{ml}$ of $\mathrm{CH}_{4}$.

\subsection{Gas analysis}

The headspace concentration of $\mathrm{CH}_{4}$ was determined with a Chrompack CP 9000 chromatograph using a flame ionization detector (FID). Helium was used as carrier gas. The analysis was carried out under the following conditions: injector temperature $65^{\circ} \mathrm{C}$, oven temperature $35^{\circ} \mathrm{C}$, and detector temperature $150^{\circ} \mathrm{C}$. A stainless steel column with NaI-inactivated alumina (100-120 mesh) stationary phase was used for separation. The chromatograms were registered and analyzed using the Thermo Separation System "WOW" software package. $\mathrm{CO}_{2}$ was determined with a Shimadzu 14 B GC using an electron capture detector (ECD). Nitrogen was used as carrier gas. The analysis was carried out under the following conditions: injector temperature $100^{\circ} \mathrm{C}$, oven temperature $35^{\circ} \mathrm{C}$, and detector temperature $250^{\circ} \mathrm{C}$. Gases were separated on a 1-m Porapak-Q pre-column (80-100 mesh, outer diameter 0.3 $\mathrm{cm}$ ), followed by a 2-m column with the same characteristics. A backflush valve between the pre-column and the main column was used for protection of the dectctor. The chromatograms were registered and analyzed using the "SHIMADZU CLASS VP" software package.

\section{Results and Discussion}

Table 2 shows the respiration rate of the different types of compost. A high $\mathrm{CO}_{2}$ production rate shows high levels of microbial activity, indicating that the compost is still decomposing. In theory, $\mathrm{CO}_{2}$ production can also result from inorganic sources (carbonates), but since no major changes in the compost properties 
(like a $\mathrm{pH}$ decrease leading to carbonate dissolution and $\mathrm{CO}_{2}$ release) were imposed prior to the experiment, such effects will be negligible. It was expected that the $\mathrm{CH}_{4}$ oxidation potential would be low when the compost is not yet stable and respiration rate is high. Therefore, we tested the relationship between respiration rate and $\mathrm{CH}_{4}$ oxidation. However, no relation between the oxidation potential and respiration rate was observed. Only two garden waste composts (G1 and G3) showed a significant $\mathrm{CH}_{4}$ oxidation activity even after one month of incubation and hence these composts were used for further study of $\mathrm{CH}_{4}$ uptake rates and of the effect of temperature and moisture content on $\mathrm{CH}_{4}$ oxidation. Both composts had a low inorganic $\mathrm{N}$ and salt content in comparison with the other composts tested.

\subsection{Effect of incubation time}

Figure 1 shows the $\mathrm{CH}_{4}$ oxidation rate as a function of time at $45 \%$ moisture content for G1 and 52\% moisture content for G3 at $22 \pm 1{ }^{\circ} \mathrm{C}$. After an initial lag phase at low activity, the compost evolved to a more active phase and showed a peak activity after 20-25 days of incubation. Thereafter the activity started to decline. A similar phenomenon was observed by Kightley et al. (1995), Hilger et al. (2000), and De Visscher and Van Cleemput (2003) in soils, and by Wilshusen et al. (2004b) in compost. In some studies the peak occurred after a few days (De Visscher et al. (1999, 2001), De Visscher and Van Cleemput (2003) for soils; Wilshusen et al. (2004b) for leaf compost and municipal solid waste compost), whereas in some studies $\mathrm{CH}_{4}$ oxidation developed gradually over several weeks (Hilger et al. (2000) for soils; Wilshusen et al. (2004b) for wood chip compost). The peak activity of G1 was 1.81 $\mu$ mol $\mathrm{kg}_{\mathrm{dw}}{ }^{-1} \mathrm{~s}^{-1}$, while for G3 it was $0.82 \mu \mathrm{mol} \mathrm{kg} \mathrm{dw}^{-1} \mathrm{~s}^{-1}$. In compost G1, the peak activity was observed for about 5 days and was followed by a gradual decrease of the 
activity. The peak activity in compost G3 lasted only 2 days and was followed by a rapid decline. Average activity after the decline was $0.61 \mu \mathrm{mol} \mathrm{kg}_{\mathrm{dw}}{ }^{-1} \mathrm{~s}^{-1}$ and 0.18 $\mu \mathrm{mol} \mathrm{kg} \mathrm{dw}^{-1} \mathrm{~s}^{-1}$ for $\mathrm{G} 1$ and $\mathrm{G} 3$, respectively.

The observed decline can be due to exopolymer production (Hilger et al., 1999; 2000; Wilshusen et al., 2004a,b), or due to depletion of nutrients (De Visscher et al., 1999, 2003). As there was no visible slime production in the samples, we assume the latter to be more probable in the present experiment. De Visscher et al. (1999) observed that methane oxidation rates stay stable for several months after the activity decline. Sometimes a resurge of the activity is observed after 2-3 months (De Visscher and Van Cleemput, 2003).

\subsection{Moisture response experiments}

Figure 2 and 3 show the influence of moisture content on the $\mathrm{CH}_{4}$ oxidation rate by compost G1 and G3, respectively. At $110 \%$ moisture content compost G1 had a maximum oxidation rate of $2.05 \mu \mathrm{mol} \mathrm{kg} \mathrm{dw}^{-1} \mathrm{~s}^{-1}$ as observed on day 5 (Figure 2). Thereafter, the rate decreased to below $1 \mu \mathrm{mol} \mathrm{kg}_{\mathrm{dw}}{ }^{-1} \mathrm{~s}^{-1}$ on day 15 and increased slightly to $1.16 \mu \mathrm{mol} \mathrm{kg} \mathrm{dw}^{-1} \mathrm{~s}^{-1}$ towards the end of the experiment. At $85 \%$ moisture content pattern was similar but a maximum activity of about $2.35 \mu \mathrm{mol} \mathrm{kg} \mathrm{dw}^{-1} \mathrm{~s}^{-1}$ was observed on day 5 . The pattern was similar at $65 \%$ moisture content, but it did not show a recovery of the activity after 2 weeks. At $45 \%$ moisture content a maximum activity of about $1.51 \mu \mathrm{mol} \mathrm{kg} \mathrm{dw}^{-1} \mathrm{~s}^{-1}$ was reached on day 9 and showed only slight decrease afterwards. At this moisture content the samples showed more steady behaviour. The activity was low throughout the experiment at $29 \%$ moisture content. The optimum moisture content was found to be $45-85 \%$, and was time-dependent. The observed trends tended to slow down with decreasing moisture content. 
Unlike sample G1, sample G3 showed highest $\mathrm{CH}_{4}$ oxidising activity at $110 \%$ moisture content throughout the experiment (Figure 3). Except at low moisture contents, the $\mathrm{CH}_{4}$ oxidation rate increased steadily during the entire experiment. Oxidation rates for different moisture contents of G3 were in the following order, $110>85>65>45>29 \%$. Apparently, the range of moisture contents examined was too narrow to determine the optimum.

The optimum moisture content of compost G1 (31\% organic matter) and G3 (52\% organic matter) for $\mathrm{CH}_{4}$ oxidation were $45-85 \%$ and $\geq 110 \%$ moisture on a dry weight basis, respectively. These values are much higher than the optimum for mineral soils with 1 to a few percents of organic matter, which is typically around 15\% (Whalen and Reeburgh, 1996; Boeckx and Van Cleemput, 1996). For a bog soil containing about $90 \%$ organic matter, on the other hand, a value on the order of $350 \%$ has been reported (Whalen and Reeburgh, 1996). Organic matter appears to be the key property determining the optimum moisture content for $\mathrm{CH}_{4}$ oxidation.

These results indicate that the $\mathrm{CH}_{4}$ oxidation potential of compost $\mathrm{G} 3$ was not really lower than the $\mathrm{CH}_{4}$ oxidation potential of compost $\mathrm{G} 1$, as could be expected from the results in the previous section. Rather, G1 was close to optimal moisture content during the first experiment, whereas G3 was not. The three inactive composts (GFT1, GFT2 and G2) had substantially lower moisture contents than the active composts and higher organic matter content than G1. This may well explain their inactivity, as their optimum moisture content was probably around 100\%, 2.5-3.5 times the moisture content at the time of the experiment. Another reason for the lack of activity might be the high inorganic nitrogen content of these composts. It is concluded that tests for $\mathrm{CH}_{4}$ oxidation potential in composts should not be limited to the natural moisture content obtained by the composting process. 


\subsection{Temperature response experiments}

The effect of temperature on the evolution of the $\mathrm{CH}_{4}$ oxidation rate is shown in Figure 4 and 5. In the case of $\mathrm{G} 1$ at $22^{\circ} \mathrm{C}$, maximum oxidation rate of $1.68 \mu \mathrm{mol}$ $\mathrm{kg}_{\mathrm{dw}}{ }^{-1} \mathrm{~s}^{-1}$ was observed on day 9 while at $30^{\circ} \mathrm{C}$, maximum oxidation rate observed was $1.65 \mu \mathrm{mol} \mathrm{\textrm {kg } _ { \mathrm { dw } }}{ }^{-1} \mathrm{~s}^{-1}$ on day 6 after the start of the experiment. A much lower activity was observed at $7^{\circ} \mathrm{C}$. Maximum oxidation observed at this temperature was $0.15 \mu \mathrm{mol} \mathrm{kg}_{\mathrm{dw}}{ }^{-1} \mathrm{~s}^{-1}$ on day 9 . The general shape of the curve on day 6 is very similar to results obtained with soils (De Visscher et al., 2001; Whalen and Reeburgh, 1996) with an optimum temperature of $30^{\circ} \mathrm{C}$. However, on day 14 the temperature response was very different, with no significant influence between 15 and $30^{\circ} \mathrm{C}$. A similar observation was also made on day 26. On the long term almost no influence of temperature between 15 to $30^{\circ} \mathrm{C}$ was observed.

Compost G3 showed a much slower and more erratic response (Fig. 5). This is probably due to the sub-optimal moisture content of these samples.

The changing patterns observed in G1 can be explained in terms of shifts in the methanotrophic population present in the compost. Gebert et al. (2003) and Börjesson et al. (2004) found that enriching methanotrophic mixed cultures at low temperature $\left(10^{\circ} \mathrm{C}\right)$ lead to a pronounced predominance of type I methanotrophic strains with lower optimum temperature $\left(22^{\circ} \mathrm{C}\right.$ instead of $\left.38^{\circ} \mathrm{C}\right)$. It is assumed that the composts incubated at $15^{\circ} \mathrm{C}$ developed a more psychrophilic population than the composts incubated at higher temperatures.

\subsection{Compost as landfill cover material}


In our study with compost, the maximum activity observed was $1.812 \mu \mathrm{mol}$ $\mathrm{kg}_{\mathrm{dw}}{ }^{-1} \mathrm{~s}^{-1}$ on day 23 after the start of the experiment. This value refers to $\mathrm{CH}_{4}$ mixing ratios of several percents, which is substantially higher than the Michaelis-Menten half-saturation constant $\left(K_{\mathrm{m}}\right)$ typically encountered with $\mathrm{CH}_{4}$ oxidation (usually $<1 \%$ ). Also, the $\mathrm{CH}_{4}$ oxidation was zero-order. Therefore, it is assumed that the values reported here approach $V_{\max }$. De Visscher et al. (2001) have reported a $V_{\max }$ value of $0.820 \mu \mathrm{mol} \mathrm{kg}_{\mathrm{dw}}{ }^{-1} \mathrm{~s}^{-1}$ in soil on day 34 after the start of an incubation experiment, while Whalen et al. (1990) have reported a $V_{\max }$ value of $0.039 \mu \mathrm{mol} \mathrm{kg}_{\mathrm{dw}}{ }^{-1} \mathrm{~s}^{-1}$ in soil samples that were taken from a landfill.

Streese and Stegmann (2003) observed a $V_{\max }$ value of $2.43 \mu \mathrm{mol} \mathrm{kg}_{\mathrm{dw}}{ }^{-1} \mathrm{~s}^{-1}$ in compost, which was a mixture of an equal volume of yard waste, peat and squeezed spruce wood fibre. Wilshusen et al. (2004a) observed a $V_{\max }$ value of $3.77 \mu \mathrm{mol} \mathrm{kg}_{\mathrm{dw}}{ }^{-1}$ $\mathrm{s}^{-1}$ after one month and $2.77 \mu \mathrm{mol} \mathrm{kg} \mathrm{dw}^{-1} \mathrm{~s}^{-1}$ after two months in compost, which was prepared from municipal green waste such as leaves mixed with manure. Values of $V_{\max }$ are not easy to interpret mechanistically because they are the result of both the number of micro-organisms in the medium and their activity (Bender and Conrad, 1992; Dunfield and Conrad, 2000). The lower values found in our study in comparison with the results of Wilshusen et al. (2004a) are probably due to the fact that the incubation of the samples of Wilshusen et al. (2004a) were at higher $\mathrm{CH}_{4}$ concentrations (>30\%). Also, $\mathrm{CH}_{4}$ concentrations were rapidly depleted in our batch experiments when the activity was high, leading to daily periods of $\mathrm{CH}_{4}$ limitation in the compost samples. Another reason could be the difference in composition of the compost starting material.

In spite of these limitations, the activities found in our study were substantially higher in compost than the activity normally found in soils. Furthermore, compost has 
more air-filled pore space than soils (on the order of 50\% compared to $20-30 \%$ for soils). Therefore it will allow more oxygen to penetrate for the oxidation of $\mathrm{CH}_{4}$ and create a more extended aerobic zone in the cover. Also, Barlaz et al. (2004) argued that the use of compost avoids the occurrence of cracks in the landfill cover, reducing the risk of emission hot spots. Hence compost is expected to be a better material for biological $\mathrm{CH}_{4}$ oxidation than soils. Nevertheless, suitability of compost as a cover material should be evaluated on a site-by-site basis, as compost has a lower density than soil, leading to lower potential contact between $\mathrm{CH}_{4}$ molecules and the microorganisms, and because high-porosity substrates might dry out more quickly. Furthermore, Barlaz et al. (2004) reported that compost covers can also produce $\mathrm{CH}_{4}$ if the moisture content is too high. Berger et al. (2005) observed that a clear borderline between cover layers with different properties can lead to water accumulation. The use of soil-compost mixtures might be a solution here.

\subsection{Application of compost as low cost approach}

The applicability of compost as cover material to reduce greenhouse gas emissions was theoretically assessed for the Gazipur landfill site in Delhi, India. It is an unplanned landfill site and has no collection system for $\mathrm{CH}_{4}$ recovery. Mor et al. (submitted manuscript) have estimated that $36-71 \mathrm{~m}^{3} \mathrm{CH}_{4} \mathrm{~m}^{-2} \mathrm{yr}^{-1}$ corresponding to 51-101 $\mu \mathrm{mol} \mathrm{CH}_{4} \mathrm{~m}^{-2} \mathrm{~s}^{-1}$ is produced from this site. Many approaches can be applied to reduce such emissions but they require a proper design and plans for landfills and hence may be costly. The application of compost as cover material offers a low cost approach to reduce such emissions and hence is suitable for the developing countries.

Based on the emission estimates of Mor et al. (submitted manuscript) and a steady state activity of $0.61 \mu \mathrm{mol} \mathrm{kg} \mathrm{dw}^{-1} \mathrm{~s}^{-1}$, it is estimated that a compost dry weight 
of $83-165 \mathrm{~kg}$ is needed to oxidise all $\mathrm{CH}_{4}$ emitted by $1 \mathrm{~m}^{2}$ of landfill. Assuming a compost bulk density of $600 \mathrm{~kg}$ fresh weight per $\mathrm{m}^{3}$ and a moisture content of $100 \%$ (dry weight basis), a compost layer of $28-55 \mathrm{~cm}$ can theoretically oxidise all $\mathrm{CH}_{4}$ emitted by the Gazipur landfill site. Assuming that the steady-state activity is representative to long-term application of compost cover soils, it can be an adequate option for mitigating $\mathrm{CH}_{4}$ emission from this landfill.

Besides, compost can be prepared from organic waste at the landfill site. Therefore, there will be no extra cost in transporting soil from another place. Hence, promoting microbial $\mathrm{CH}_{4}$ oxidation within a cover soil can be a good management practice for designing and managing the landfill cover. This is a cheap and effective option for reducing emissions from smaller and older landfills with lower amounts of $\mathrm{CH}_{4}$ generation making gas extraction economically less beneficial.

\section{Conclusion}

The temporal patterns of $\mathrm{CH}_{4}$ oxidation rates observed in compost were similar to the patterns observed previously. The influence of temperature and moisture content on $\mathrm{CH}_{4}$ oxidation was time-dependent. The temperature response tended to be flatter at longer incubation times. It is hypothesized that this is the result of a shift towards more psychrophilic methanotrophs during incubation at a temperature of $15^{\circ} \mathrm{C}$ in comparison with higher temperatures. The moisture response of $\mathrm{CH}_{4}$ oxidation was also time-dependent in one of the composts tested. When comparing composts for their suitability as a landfill biocap, care should be taken to optimize moisture conditions for $\mathrm{CH}_{4}$ oxidation. Compost has a significant potential to oxidize $\mathrm{CH}_{4}$ and hence it can be used as cover material to reduce the emission of this greenhouse gas from landfills. Calculations show that complete oxidation of the 
methane produced in the Gazipur landfill in Delhi, India, could be feasible if the activities observed can be sustained for a sufficiently long time.

\section{Acknowledgement}

VLACO, Mechelen, Belgium, is acknowledged for the compost samples and their analysis. This research was made possible by a fellowship from the Ministry of Human Resources and Development, Government of India in collaboration with the Belgian government. 


\section{References}

Adamsen, A.P.S. and G.M. King, 1993. Methane consumption in temperate and subarctic forest soils: rates, vertical zonation and responses to water and nitrogen. Applied and Environmental Microbiology 59, 485-490.

Barlaz, M.A., R.B. Green, J.P. Chanton, C.D. Goldsmith, and G.R. Hater, 2004. Evaluation of a biologically active cover for mitigation of landfill gas emissions. Environmental Science \& Technology 38, 4891-4899.

Bender, M. and R. Conrad, 1992. Kinetics of $\mathrm{CH}_{4}$ oxidation in oxic soils exposed to ambient air or high $\mathrm{CH}_{4}$ mixing ratios. FEMS Microbiology Ecology 101, 261270.

Bender, M. and R. Conrad, 1995. Effect of $\mathrm{CH}_{4}$ concentrations and soil conditions on the induction of $\mathrm{CH}_{4}$ oxidation activity. Soil Biology and Biochemistry 27, 15171527.

Berger J., Fornés L.V., Ott C., Jager J., Wawra B. and Zanke U. 2005. Methane oxidation in a landfill cover with capillary barrier. Waste Management 25, 369373.

Bodelier P.L.E. and H.J. Laanbroek, 2004. Nitrogen as a regulatory factor of methane oxidation in soils and sediments. FEMS Microbiology Ecology 47, 265-277.

Boeckx, P. and O. Van Cleemput, 1996. Methane oxidation in a neutral landfill cover soils: influence of moisture content, temperature and nitrogen turnover. Journal of Environmental Quality 25, 178-183.

Bogner, J. and E. Matthews, 2003. Global methane emissions from landfills: New methodology and annual estimates 1980-1996. Global Biogeochemical Cycles 17(2), 1065, doi:10.1029/2002GB001913. 
Bogner, J., M. Meadows, and P. Czepiel, 1997. Fluxes of methane between landfills and the atmosphere: natural and engineered controls. Soil Use and Management $13,268-277$.

Börjesson, G., J. Chanton, and B.H. Svensson, 2001. Methane oxidation in two Swedish landfill covers measured with carbon-13 to carbon-12 isotope ratios. Journal of Environmental Quality 30, 369-376.

Börjesson, G., I. Sundh, and B. Svensson, 2004. Microbial oxidation of $\mathrm{CH}_{4}$ at different temperatures in landfill cover soils. FEMS Microbiology Ecology 48, 305-312.

Chanton, J. and K. Liptay, 2000. Seasonal variation in methane oxidation in a landfill cover soil as determined by an in situ stable isotope technique. Global Biogeochemical Cycles 14, 51-60.

De Visscher, A., D. Thomas, P. Boeckx, and O. Van Cleemput, 1999. Methane oxidation in simulated landfill cover soil environments. Environmental Science \& Technology 33, 1854-1859.

De Visscher, A., M. Schippers, and O. Van Cleemput, 2001. Short-term kinetic response of enhanced methane oxidation in landfill cover soils to environmental factors. Biology and Fertility of Soils 33, 231-237.

De Visscher, A. and O. Van Cleemput, 2003. Induction of enhanced $\mathrm{CH}_{4}$ oxidation in soils: $\mathrm{NH}_{4}{ }^{+}$inhibition patterns. Soil Biology and Biochemistry 35, 907-913.

Doorn, M. and M. Barlaz, 1995. Estimate of global methane emissions from landfills and open dumps. Report EPA-600/SR-95-019.U.S. EPA, Washington, D.C.

Dunfield, P.F. and R. Conrad, 2000. Starvation alters the apparent half-saturation constant for methane in the type II methanotroph Methylocystis strain LR1. Applied and Environmental Microbiology 66, 4136-4138. 
Gebert, J., A. Groengroeft, and G. Miehlich, 2003. Kinetics of microbial landfill methane oxidation in biofilters. Waste Management 23, 609-619.

Hilger, H.A., S.K. Liehr, and M.A. Barlaz, 1999. Exopolysaccharide control of methane oxidation in landfill cover soil. Journal of Environmental Engineering $125,1113-1123$.

Hilger, H.A., D.F. Cranford, and M.A. Barlaz, 2000. Methane oxidation and microbial exopolymer production in landfill cover soil. Soil Biology and Biochemistry 32, 457-467.

Humer, M. and P. Lechner, 1999. Alternative approach to the elimination of greenhouse gases from old landfills. Waste Management and Research 17, 443452.

Humer, M. and P. Lechner, 2001. Microbial methane oxidation for the reduction of landfill gas emissions. Journal of Solid Waste Technology and Management 27, $146-151$

Intergovernmental Panel on Climate Change (IPCC), 2001. Technical Summary, In: Climate change 2001: The Scientific Basis. Cambridge University Press.

Kightley, D., D.B. Nedwell, and M. Cooper, 1995. Capacity for methane oxidation in landfill cover soils measured in laboratory scale microcosms. Applied and Environmental Microbiology 61, 592-601.

King, G.M. and A.P.S. Adamsen, 1992. Effects of temperature on methane oxidation in forest soil and pure cultures of the methanotroph Methylomonas rubra. Applied and Environmental Microbiology 58, 2758-2763.

Lelieveld, J., P.J. Crutzen, and F.J. Dentener, 1998. Changing concentration, lifetime and climate forcing of atmospheric methane. Tellus 50B, 128-150. 
Meadows, M., C. Franklin, D. Campbell, and P. Riemer, 1997. Global methane emissions from solid waste disposal sites, In: Proceedings Sardinia 1997, Sixth International Landfill Symposium, Cagliari, Italy, CISA, pp 3-10.

Reeburgh, W.S., S.C. Whalen, and M.J. Alperin, 1993. The role of methylotrophy in the global methane budget. In: Microbial Growth on Cl Compounds (Murrell, J.C. and D.P. Kelly, Eds), Intercept Ltd., Andover, U.K., pp. 1-14.

Stein, V.B. and J.P.A. Hettiaratchi, 2001. Methane oxidation in three Alberta soils: Influence of soil parameters and methane flux rates. Environmental Technology 22, 101-111.

Streese, J. and R. Stegmann, 2003. Microbial oxidation of methane from old landfills in biofilters. Waste Management 23, 573-580.

Visvanathan, C., D. Pokhrel, W. Chiemchaisri, J.P.A. Hettiaratchi, and J.S. Wu, 1999. Methanotrophic activities in tropical landfill cover soils: Effects of temperature, moisture content and methane concentration. Waste Management and Research 17, 313-323.

Whalen, S.C. and W.S. Reeburgh, 1996. Moisture and temperature sensitivity of $\mathrm{CH}_{4}$ oxidation in boreal soils. Soil Biology and Biochemistry 28, 1271-1281.

Whalen, S.C., W.S. Reeburgh, and K.A. Sandbeck, 1990. Rapid methane oxidation in a landfill cover soil. Applied and Environmental Microbiology 56, 3405-3411.

Wilshusen, J.H., J.P.A. Hettiaratchi, A. De Visscher, and R. Saint-Fort, 2004a. Methane oxidation and formation of EPS in compost: effect of oxygen concentration. Environmental Pollution 129, 305-314.

Wilshusen, J.H., J.P.A. Hettiaratchi, and V.B. Stein, 2004b. Long-term behavior of passively aerated compost methanotrophic biofilter columns. Waste Management 24, 643-653. 
Table 1

Characteristics of different types of compost

\begin{tabular}{|c|c|c|c|c|c|c|}
\hline Parameter & GFT1 & GFT2 & G1 & G2 & G3 & Unit \\
\hline Moisture content & 29.2 & 41.4 & 49.5 & 36.8 & 58.5 & $\mathrm{wt} \%^{\mathrm{a}}$ \\
\hline E.C. $(1 / 5)$ & 2410 & 2010 & 971 & 1750 & 688 & $\mu \mathrm{S} / \mathrm{cm}$ \\
\hline $\mathrm{pH}$ (water) & 8.8 & 8.8 & 8.3 & 7.4 & 6.7 & - \\
\hline Chloride & 1767 & 1575 & n.d. ${ }^{\mathrm{c}}$ & 1650 & 700 & $\mathrm{mg} / \mathrm{l}$ \\
\hline Organic matter content & 39.1 & 42.9 & 31.1 & 38.2 & 52.1 & $\mathrm{wt} \%$ \\
\hline Total nitrogen & 1.81 & 1.53 & 1.54 & 1.46 & 1.08 & $\mathrm{wt} \%$ \\
\hline $\mathrm{NH}_{4}-\mathrm{N}$ & 131.0 & 343.0 & 14.0 & $<25$ & 86.0 & $\mathrm{mg} / \mathrm{l}$ \\
\hline $\mathrm{NO}_{3}-\mathrm{N}$ & 118.0 & $<25$ & 130.0 & 350.0 & $<25$ & $\mathrm{mg} / \mathrm{l}$ \\
\hline $\mathrm{C} / \mathrm{N}$ & 12.0 & 15.6 & 11.2 & 14.5 & 26.9 & - \\
\hline \multicolumn{7}{|l|}{ Total nutrient content } \\
\hline Total $\mathrm{P}_{2} \mathrm{O}_{5}$ & 0.88 & 0.58 & n.d. & 0.43 & 0.25 & wt $\%$ \\
\hline Total $\mathrm{K}_{2} \mathrm{O}$ & 1.36 & 1.15 & n.d. & 1.06 & 0.58 & wt $\%$ \\
\hline Total $\mathrm{CaO}$ & 2.91 & 2.25 & n.d. & 1.93 & 1.41 & $\mathrm{wt} \%$ \\
\hline Total $\mathrm{MgO}$ & 0.65 & 0.47 & n.d. & 0.37 & 0.20 & $\mathrm{wt} \%$ \\
\hline \multicolumn{7}{|l|}{ Extractable content } \\
\hline Extractable P & 752 & 794 & n.d. & 698 & 173 & $\mathrm{mg} / \mathrm{l}$ \\
\hline Extractable K & 3587 & 4947 & n.d. & 5381 & 2447 & $\mathrm{mg} / \mathrm{l}$ \\
\hline Extractable $\mathrm{Ca}$ & 2946 & 4652 & n.d. & 5674 & 1985 & $\mathrm{mg} / \mathrm{l}$ \\
\hline Extractable $\mathrm{Mg}$ & 639 & 510 & n.d. & 773 & 466 & $\mathrm{mg} / \mathrm{l}$ \\
\hline
\end{tabular}

${ }^{\mathrm{a}}$ All weight fractions are on a dry weight basis

b Volumes used for expressing concentrations in compost are bulk volumes. For approximate mass fractions in $\mathrm{mg} \mathrm{kg}^{-1}$, multiply by 2 .

${ }^{\mathrm{c}}$ n.d.: not determined 
Table 2

Respiration rate of the compost

\begin{tabular}{cc}
\hline Compost & $\mathrm{mmol} \mathrm{CO}_{2} / \mathrm{kg}_{\mathrm{dw}} / \mathrm{day}$ \\
\hline GFT1 & 4.10 \\
GFT2 & 15.12 \\
G1 & 6.28 \\
G2 & 2.96 \\
G3 & 8.75 \\
\hline
\end{tabular}




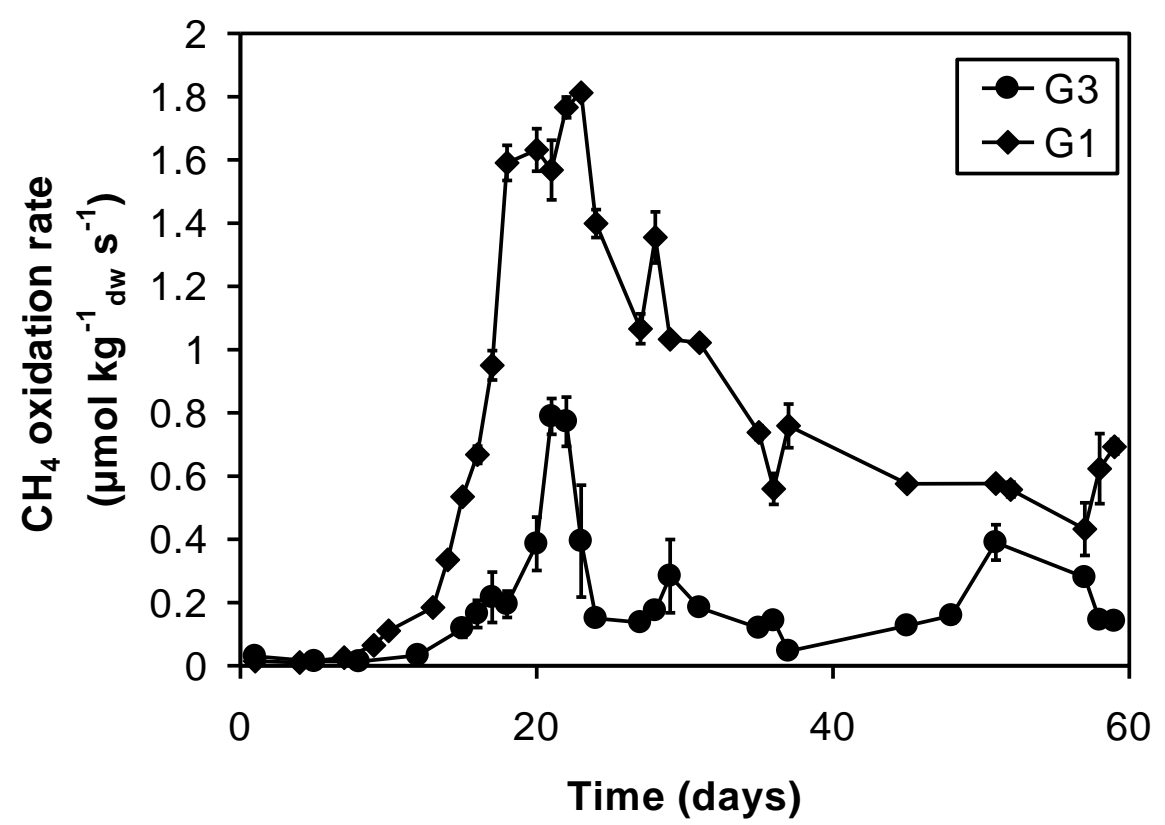

Fig. 1. $\mathrm{CH}_{4}$ oxidation rate observed in two composts over a period of 60 days at $22^{\circ} \mathrm{C}$. Error bars are standard deviation. 

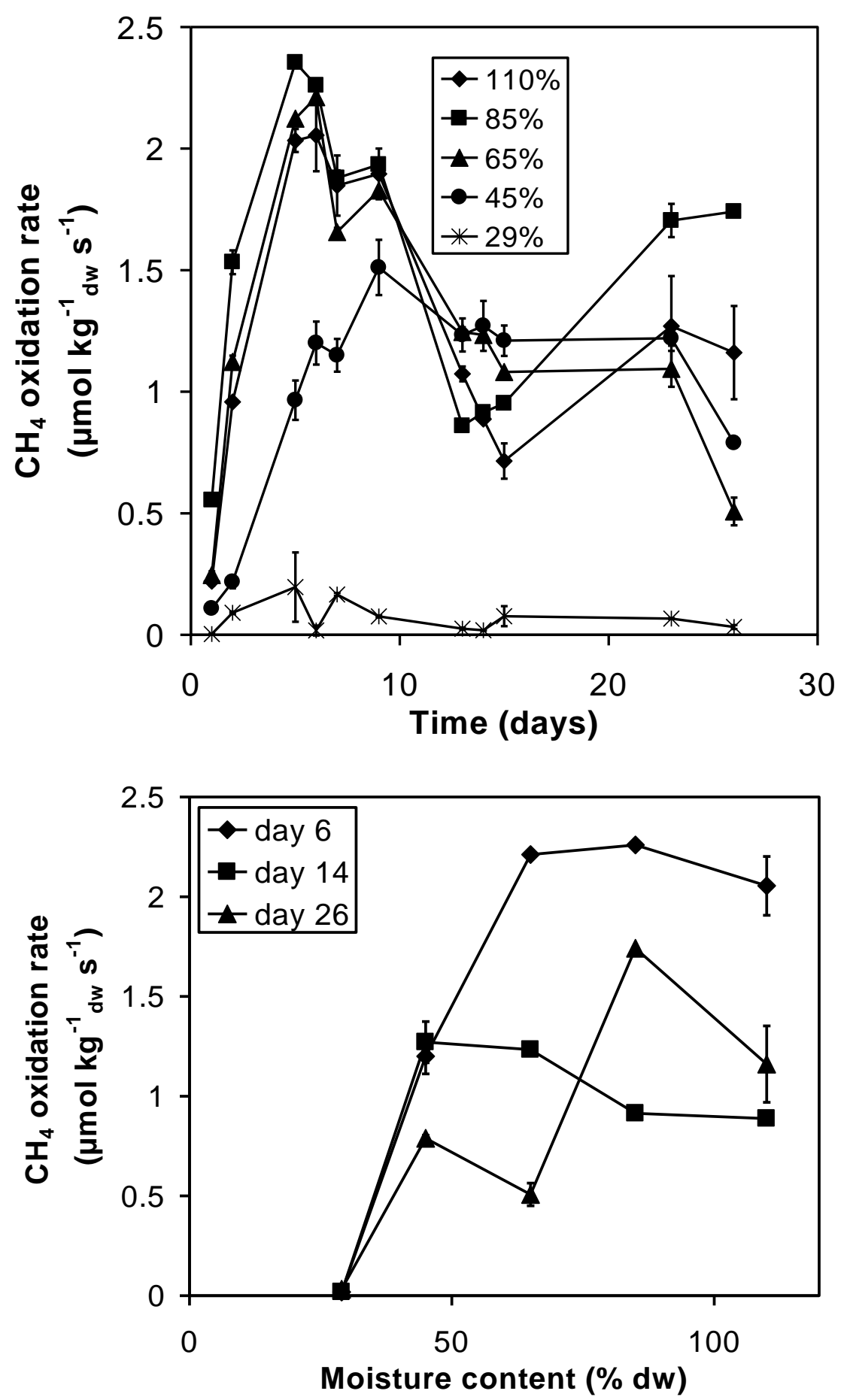

Fig. 2. Effect of moisture content on $\mathrm{CH}_{4}$ oxidation rate by compost $\mathrm{G} 1$ versus time. Error bars are standard deviation. 

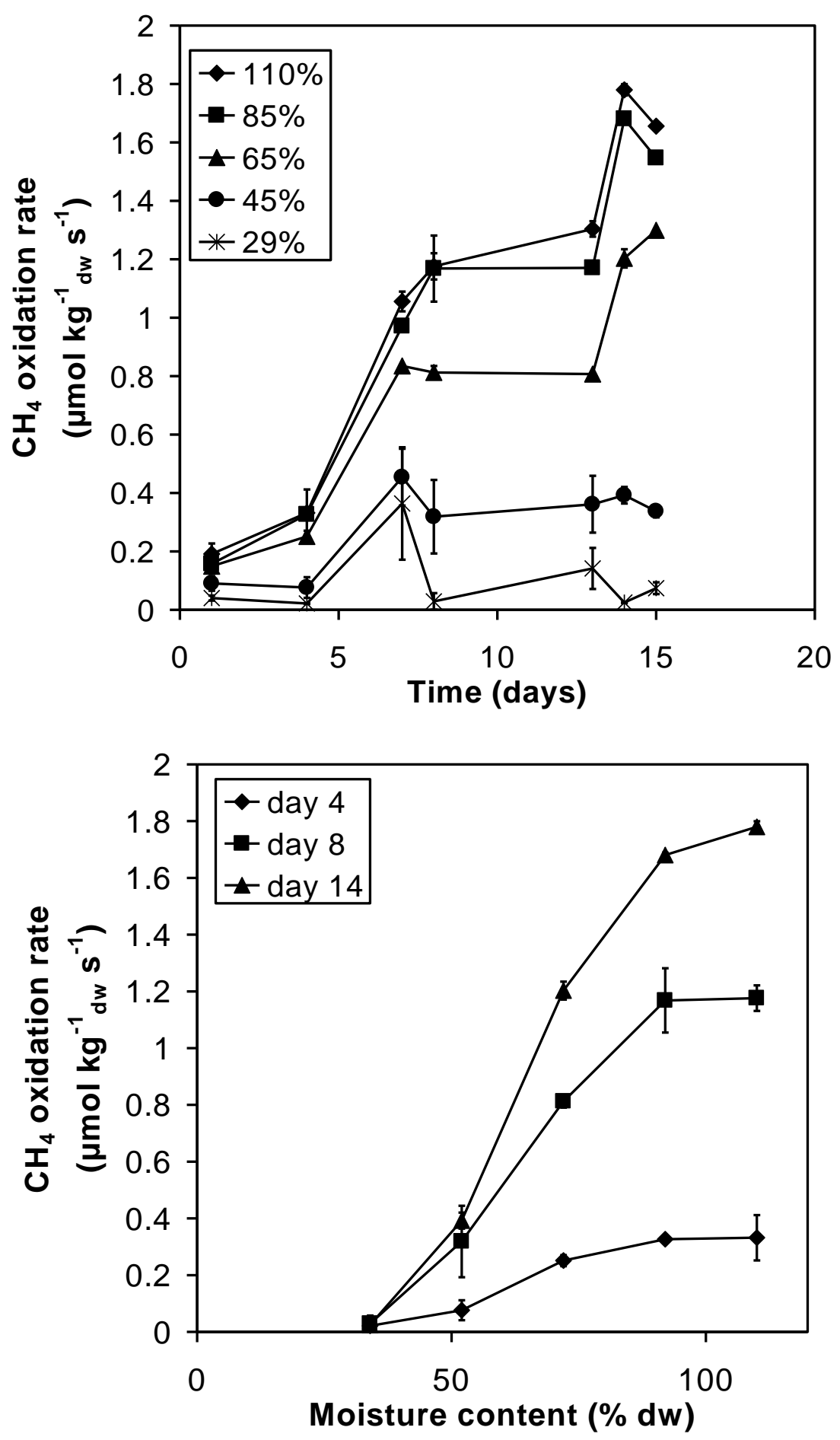

Fig. 3. Effect of moisture content on the $\mathrm{CH}_{4}$ oxidation rate by compost $\mathrm{G} 3$ versus time. Error bars are standard deviation. 

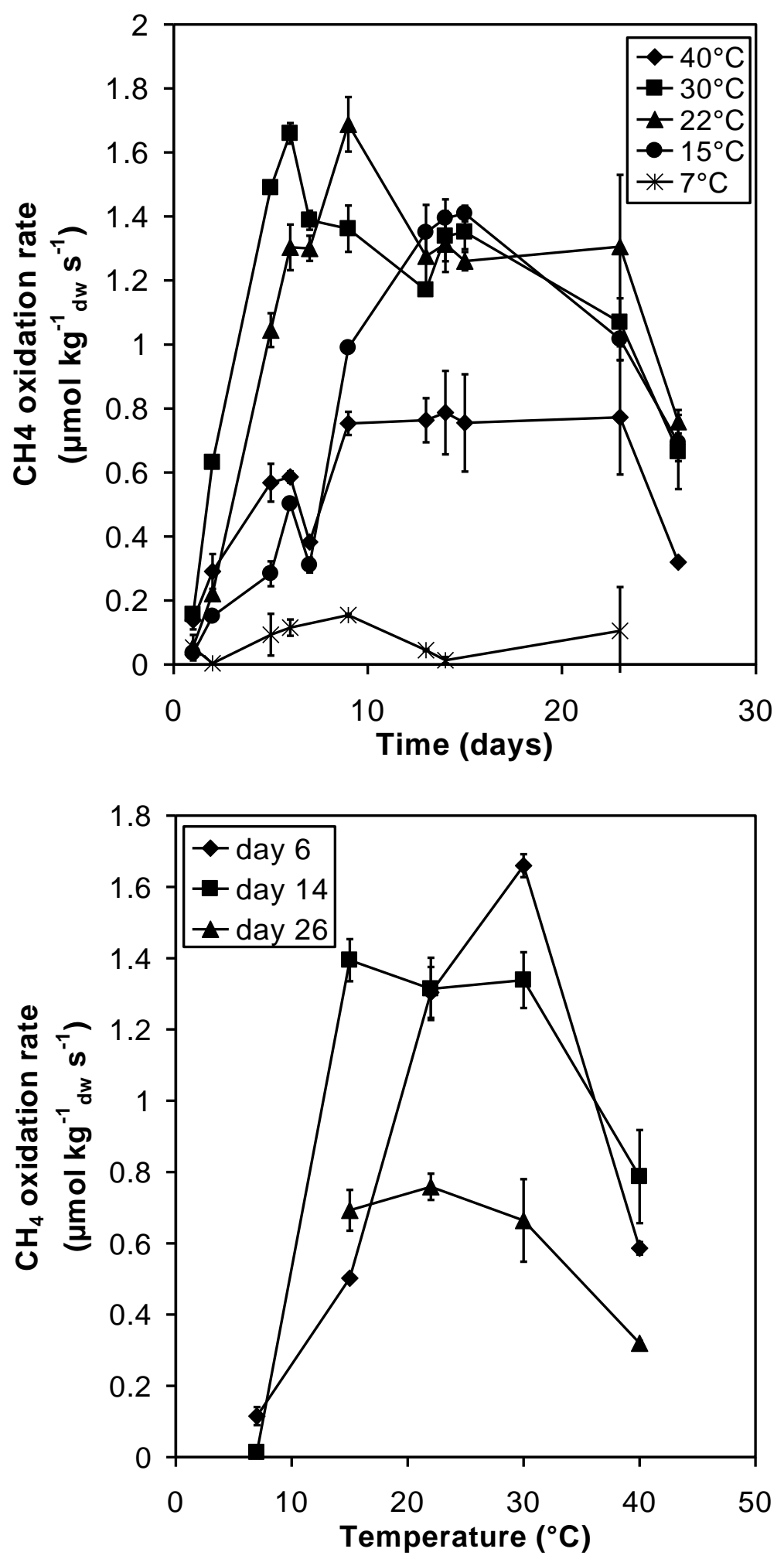

Fig. 4. Effect of temperature on the $\mathrm{CH}_{4}$ oxidation rate by compost $\mathrm{G} 1$ versus time. Error bars are standard deviation. 

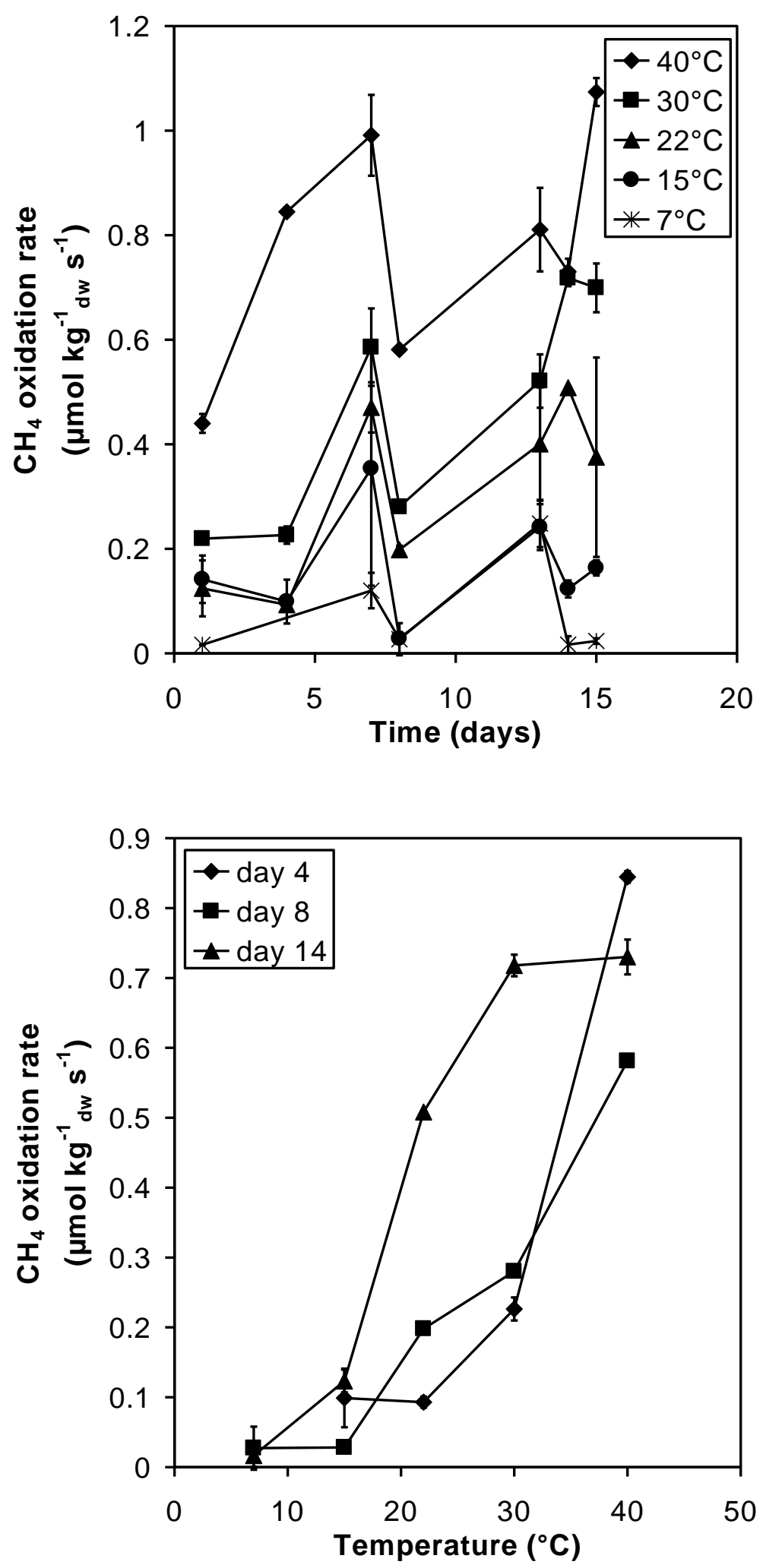

Fig. 5. Effect of temperature on the $\mathrm{CH}_{4}$ oxidation rate by compost $\mathrm{G} 3$ versus time. Error bars are standard deviation. 